\title{
Appraisal of Veritable Leadership Characters Exhibited by Secondary School Principals: A Case of Osun State Secondary Schools, Nigeria
}

\author{
Olowo Busuyi Francis ${ }^{1}$ \\ ${ }^{1}$ Department of Educational Management, Faculty of Education, Obafemi Awolowo University, Ile Ife, \\ Nigeria \\ Correspondence: Olowo Busuyi Francis, Obafemi Awolowo University, Ile Ife, Nigeria. \\ Email: olowo4404@gmail.com
}

Doi: 10.23918/ijsses.v7i3p73

\begin{abstract}
This paper reports the results of a survey that appraised the leadership characters exhibited by secondary school principals in Osun State Secondary Schools, Nigeria. The study adopted quantitative approach of design. Population of the study comprised all 7,767 teachers and sample of 390 was selected using simple random and purposive sampling techniques. An instrument was used to gather data. Data collected were analysed using mean, standard deviation (SD) and T-Test. The findings showed that principals demonstrated their accountability $(\bar{x}=3.09)$, courageous $(\bar{x}=3.07)$, justice $(\bar{x}=3.02)$, and, collaborative $(\bar{x}=2.95)$ characters. The study further indicated that there was no significant difference between the courageous $(t-$ cal $=64.91 ; \mathrm{df}=310 ; \mathrm{p}(\mathbf{0 . 6 1 2})>0.05)$, collaborative $(\mathrm{t}-\mathrm{cal}=71.88 ; \mathrm{df}=310 ; \mathrm{p}(\mathbf{0 . 7 3 6})>0.05)$, accountability $(\mathrm{t}-$ cal $=72.89 ; \mathrm{df}=310 ; \mathrm{p}(0.594)>0.05)$ and justice characters $(\mathrm{t}-\mathrm{cal}=69.81 ; \mathrm{df}=310 ; \mathrm{p}(0.612)>0.05)$ demonstrated by male and female principals in the study area. The study concluded that both the male and female principals in the study area exhibited their accountability, courageous, justice and collaborative characters.
\end{abstract}

Keywords: Appraisal, Leadership Characters, Principals, Secondary Schools, Nigeria

\section{Introduction}

Success of organisation largely depends on a leader who utilises the available resources appropriately. Such leader is always committed, capable, competent, well experienced and passionate to actualize goals. Ibe (2007) opines that success of a leader can be measured by how much he/she inspires others to willingly do things that will help the organization to achieve its goal. This implies that the performance of a leader can be measured by their series of achievement. Therefore, leadership is essential to accomplish organisation goals. According to Taiwo (2010) and Ogbiji (2006) leadership is the ability to accomplish goals with the support as well as cooperation of other staff within the organisation. This indicates that leadership simply means ability of a leader to motivate, encourage, and influence staff to do things accordingly toward accomplishment of goals. Northouse (2007) argues that leadership is determined by approaches that a leader adopts to influence their staff. He buttresses that a good leader disregards his/her legitimate power but showing genuine interest through interaction with staff to influence their performances.

In recent times studies concentrated on identifying and upgrading to classify what makes a leader to be effective. The literature suggested that leader who is effective can be known from what they "DO" (styles), what they "KNOW" (competencies) and who they "ARE" (characters). Meanwhile what leaders "DO" connotes the engagement, actions, and styles that a leader adopts to influence his/her followers. Likewise, what leaders "KNOW" means the social and intellectual competent that a leader displays on their job. Whereby who leaders "ARE" connotes the characters that are consistent from a leader to his/her followers. 
According to researches, little was known about leadership characters of a leader that is effective (Dulewicz, Young, \& Dulewicz, 2005). Moreover, studies hardly considered how the joint combination of particular leader's characters improve and enhance their effectiveness (Zaccaro, Kemp, \& Bader, 2004; Yukl, 2006). In this context, leadership characters are habits that are relatively stable and consistent in a leader for long period of time for the purpose of accomplishing goals. Therefore, this study focuses on leaders of secondary schools.

Schools are founded essentially for the purpose of imparting knowledge, experience, skills and technical know-how to students in a formal way. In terms of the management, school head determines the success or otherwise. Meanwhile, success may be achieved by a dedicated and committed school head. In secondary school in Nigeria, school head is known as the principal. Ogbonnaya (2004), Alpha (2005) and Odibo (2001) in their different opinions regard principal as the chief executive, accounting officer as well as instructional leader of school. Ogbonnaya (2004) further discloses that among the functions of the principal, their leadership roles in the school are very crucial. According to the author, the leadership roles are exercised in the planning, organising and instructions of the principal. In the same view, Mgbodile (2004) states that principal is responsible for implementing educational programmes as well as conducive atmosphere for learning. From the above statements, principal is the number one who is responsible and accountable for all programmes in the school. At the same time, principal is expected to ensure that all programmes are appropriately planned, organized, controlled, directed and executed.

Many researchers have reported and acknowledged that principals' leadership roles were significantly enhancing the school performances as well as students' academic achievements (Kearney, 2005; Gamage, 2009). The study of Gamage et al. (2012) equally reported that principals build conducive environment that can motivate teachers to perform to expectation in the schools. Besides, in most of the school systems, the principals enhance academic performance and equally committed to motivate and energize teachers to perform (Ross \& Gray, 2006, cited in Gamage et al., 2012). The principals are equally accountable for achievement of both students and staff (Witziers, Bosker, \& Kruger, 2003). According to Ponnusamy (2010) school principals can influence the teacher's performance toward students' achievement. Meanwhile, to accomplish the influence, principals of the school are expected to be fair and not biased. They are equally expected to be very courageous, accountable, and collaborate with staff to ensure that all things are done appropriately.

However, losing leadership characters by the principals may jeopardize their leadership influence as well as their performance. Burke (2006); Allen and Klenke (2009) has earlier linked leadership failure to lack good characters. George and McLean (2007) argue that ineffective leaders had three destructive behaviors, namely disregard relationship with others, not admitting mistakes and rationalizing their failures. In same view, Bangari and Prasad (2012) regard those leaders that lack courage to do the right thing as failure leaders. Meanwhile, many teachers (staff) express dissatisfactions when their principals (leaders) demonstrated unfair and inappropriate characters in their leadership practices (Sen, Erkan, \& Yangilar, 2013). In the same view, experiences have shown that most of the principals in the study area were not fair, accountable and courageous is their administrative functions. Crossan, Gandz, and Seijts (2012) equally reported in their study that the profiles of leaders only addressed their competencies and commitment but neglected their characters. Moreover, there is little or no research about leadership 
characters exhibited by the principals in secondary schools. For these reasons, this study appraises the leadership characters exhibited by the principals in Osun State secondary schools.

\subsection{Leaders' Courage Character}

Courage was derived from French language which implies "heart and spirit". The earlier Philosophers such as Aquinas, Aristotle and Plato regard courage as cardinal virtue (Kateb, 2004). Courage simply means ability to do something in spite of fear and doubt. Courage also means to accept responsibility to change things to a new dimension. In addition, it means to go beyond the comfort by fighting for what is right (Daft, 2005). Aprigliano (2000) cited in Rijamampianina (2018) argues that courage can be developed while interacting with life situations and experiences.

Courageous leader is a person who is bold enough to look forward to identify new destination of doing things and have ability to communicate and willing to execute it. Sen, Kabak, and Yanginlar (2013) opine that courageous leader is a brave person who has heart, spirit, emotional capacity and exceptional intellectual to make drastically change in the organisation. Such leader equally takes risks and deals with difficult situations instead of overtaking them. Barker and Coy (2003) suggest that courage is required when a leader is facing risks that could harm his/her career. Likewise, Solomon (1999) suggests that courage is required when a leader is facing the threat of being fired or not being promoted. Though, the situation that the leader needs courage beyond their personal problems, a leader must also be courageous during adversity or problem that the organization encountered in accomplishing their goals.

\subsection{Leader's Collaboration Character}

The word collaboration was derived from Latin "collaborare" which means "to work together". Collaboration is a process in which responsibilities, resources and activities are jointly planned and executed for the purpose of achieving common goals (Putnik \& Cunha 2008). Dillenbourg (1999) describes collaboration as coming together of people to learn or do things together. This implies that collaboration means coming together of people under a leadership to work as a group for purpose of achieving goals. Collaboration also means sharing of decision making with staff with adequate feedback. Sanaghan and Lohndorf (2015) opine that collaboration occurs when people work with one another in a clearly mutual understanding to accomplish set of goals which cannot be achieved alone. Collaboration is important in every organization that wants to achieve their goal. Therefore, a principal is expected to take the lead in ensuring that all teachers work as a team toward the attainment of the educational goals.

\subsection{Leaders' Accountability Character}

In organization, individual is responsible to be accountable for their action and assigned duty. According to Crossan, Gandz and Seijts (2012) accountability is the willingness to accept responsibility for decisions and actions as well as taking ownership of challenging issues that may arise. To Blagescu and de Las Casas (2005); Bovens, (2007); O’Dwyer and Unerman (2007), accountability is recognized as commitment of individuals to review, demonstrate, and take responsibility for performances with their results either as expected or not. To Rutkowski and Steelman (2005), accountability means compliant with personal responsibilities by accepting obligation or action. Lello (1993) posits that accountability necessitates reporting to other people and having a moral responsibility about things. So, individual 
accountable for their actions and others in case if the one is at top of others. Therefore, the leader of the organization is responsible for his /her own action as well as the action of the subordinates. Allen and Dennis (2010) and McCall (2012) disclose that when leader is accountable for feedback, it will be an avenue to improve performance. Arnold H Glasow in Sarmad (2007) opined that good leader takes more of blame than credit. Meanwhile, it is good for a leader to allow the subordinates to equally accountable for their own actions (Sarmad, 2007).

\subsection{Leaders' Justice Character}

For someone to act with fairness, the person needs justice characters. According to Simpson (2009), justice is the quality of being righteous. In another definition from MacIntyre (1984), justice means disposition that underlies the equal treatment of others. Palencia (2012) regards justice as a process of being impartial to conflict, rewards and punishments. In the same view, Sison (2003) refers justice as a positive character that calls for equal rights among people and to establish harmony in relationships with people such that promote equity. From above definitions, justice simply means displaying act of being impartial among people or staff.

A leader in an organization needs to possess this character in order to avoid conflict among the staff in the organization. A leader needs to recognize appropriate time to display justice characters in organization. As regard to this, Kohlberg (1976) suggests that justice is required when a person is facing conflicts of interest or distributing duties among others. Moreover, Bragues (2006) suggests that justice is required during the allocation of resources that people value, such as money, property, sex, offices, power, and status. Based on these suggestion, a principal needs to demonstrate their justice characters when perceives conflict among staff and during allocation of resource.

\subsection{Objectives of the Study}

The objectives of the study are to:

1. assess the leadership courage of secondary school principals in Osun State secondary schools

2. assess the leadership collaboration of secondary school principals in Osun State secondary schools

3. assess the leadership accountability of secondary school principals in Osun State secondary schools

4. assess the leadership Justice of secondary school principals in Osun State secondary schools

\subsection{Research Questions}

The following questions were raised to guide the study

1. What are the courageous characters demonstrated by secondary school principals in Osun State secondary school?

2. What are the collaborative characters demonstrated by secondary school principals in Osun State secondary schools?

3. What are the accountability characters demonstrated by secondary school principals in Osun State secondary schools?

4. What are the justice characters demonstrated by secondary school principals in Osun State secondary school? 


\subsection{Research Hypotheses}

$\mathrm{H}_{01}$ : There is no significant difference between the courageous characters demonstrated by male and female principals in Osun state secondary schools

$\mathrm{H}_{02}$ : There is no significant difference between the collaborative characters demonstrated male and female principals in Osun state secondary schools

$\mathrm{H}_{03}$ : There is no significant difference between the accountability characters demonstrated by male and female principals in Osun state secondary schools

$\mathrm{H}_{04}$ : There is no significant difference between the justice characters demonstrated by male and female principals in Osun state secondary schools

\section{Methods}

\subsection{Research Design and Population of the Study}

The study adopted quantitative approach of design. The population of the study made up of all 7,767 teachers of Osun State secondary schools.

\subsection{Sample and Sampling Techniques}

The sample comprised 390 teachers using Taro yamane's formula to actualise the sample to use. The Taro yamane's formula is $\mathrm{n}=\mathrm{N} /\left[1+\left(\mathrm{Ne}^{2}\right)\right]$ (where, $\mathrm{n}=$ Sample size $\mathrm{N}=$ Total population, $\mathrm{e}=0.05$ (constant)) (Yamane, 1967). Simple random sampling technique was used to select seven Local Government Areas (L.G.As) from thirty local governments in Osun State. A purposive sampling technique was used to select 39 secondary schools. Purposive sampling techniques was used because the gender (male and female) was considered in selection of schools. Whereby, simple random sampling technique was used to select 10 teachers from each of the schools purposely selected. The teachers were selected to rate both male and female principals to ascertain their different characters. That is, the teachers rated the school principals according to their gender.

\subsection{Instrument for Data Collection}

An instrument title: Appraisal of Leadership Character of Secondary School Principals Questionnaire (ALCSSPQ). The questionnaire was adapted from the study conducted by Crossan et al. (2012). Though, adjustments were made so as to make the instrument suit for the location. ALCSSPQ was divided into section A, B, C, D and E. Section A contains an item on socio demographic characteristics; section B contains 7 items on leadership courage characters of secondary school principals; section $\mathrm{C}$ contains 6 items on leadership collaboration characters of secondary school principals; section D contains 7 items on leadership accountability characters of secondary school principals while section E contains 6 items on leadership justice characters of secondary school principals. For ALCSSPQ, 4-point Likert type scale of Strongly Agree $(\mathrm{SA})=4$, Agree $(\mathrm{A})=3$, Disagree $(\mathrm{D})=2$ and Strongly Disagree $(\mathrm{SD}=1$ were used for section $\mathrm{B}, \mathrm{C}, \mathrm{D}$ and $\mathrm{E}$. 


\subsection{Validity of the Instrument}

Content of the questionnaire was corrected and well scrutinized by the experts in Department of Educational Management, Faculty of Education, Obafemi Awolowo University, Ile-Ife, Nigeria in order to ensure that it measures what is to be measured.

\subsection{Reliability of the Instrument}

Test re-test method was used to determine the reliability of the study. Pilot study was done by administering the questionnaire to 39 teachers which was not part of the study but having similar characteristics at interval of 14 days. The data collected were coded and analyzed using the Pearson Moment Correlation Coefficient. A value of reliability co-efficient of 0.824 was obtained which was considered adequate for the study. The respondents used for the reliability was excluded from the study sample.

Table 1: Reliability Test Results

\begin{tabular}{cccc}
\hline Sections & No of Items & Reliability Index & Status \\
\hline B & 7 & .812 & Reliable \\
C & 6 & .873 & Reliable \\
D & 7 & .814 & Reliable \\
E & 6 & .797 & Reliable \\
Scale of Reliability & 26 & .824 & Reliable \\
\hline
\end{tabular}

\subsection{Data Collections Techniques}

Permission was granted to the researcher by each of the principals in the sampled schools to administer questionnaires to the teachers. The researcher administered the instrument within two weeks. The questionnaire was handed over to individual teacher in the sample schools. The researcher emphasized the purpose and importance of their responses to the questionnaires. The researcher also assured the teachers that their responses would be kept confidential and only be used for the purpose of this research. Some teachers reacted to the questionnaire immediately while some were collected back in the later of the day. Out of 390 questionnaires distributed to teachers, only 312 were able to retrieve from the teachers, that is, $80 \%$. Total number of $172(55.1 \%)$ teachers' ticked questionnaire of $22(56.4 \%)$ male principals while 130 (44.9\%) teachers responded to questionnaires of 17 (43.6\%) female principals. The essence of the questionnaire was for the teachers to appraise the characters of their principals

\subsection{Data Analysis Techniques}

Data collected were analyzed using descriptive and inferential statistics approach. Descriptive such as mean and standard deviation (SD) were used to answer the research questions while T-Test was used to analysed the hypotheses. The significant level was 0.05 . The interpretation of the mean scores was based on cut-off point of 2.50 , the basis for arriving at 2.50 by adding $4+3+2+1=10 / 4=2.50$. Any mean scores that was 2.50 and above was considered agreed while a mean score that was below 2.50 was considered 
disagree in the study. Statistical Packages for the Social Science (SPSS) was the tool that was used to analyze the data.

\section{Results}

Research Question 1: What are the courageous characters demonstrated by secondary school principals in Osun State secondary school?

Table 2: Mean rating of teachers on courageous characters demonstrated by Secondary School Principals

\begin{tabular}{|l|l|l|l|l|l|}
\hline S/N & ITEMS & N & Mean & SD & Decision \\
\hline 1 & $\begin{array}{l}\text { Principal does what he/she believes to be right even } \\
\text { in the face of adversity. }\end{array}$ & 312 & 2.57 & 0.67 & Agree \\
\hline 2 & $\begin{array}{l}\text { Principal resolves and stays committed to see things } \\
\text { through. }\end{array}$ & 312 & 3.71 & 0.58 & Agree \\
\hline 3 & $\begin{array}{l}\text { Principal endures and withstands difficult } \\
\text { conditions. }\end{array}$ & 312 & 2.55 & 0.51 & Agree \\
\hline 4 & Principal recovers quickly from setbacks. & 312 & 2.67 & 0.81 & Agree \\
\hline 5 & $\begin{array}{l}\text { Principal demonstrates self-assurance in his or her } \\
\text { abilities, decisions, and actions. }\end{array}$ & 312 & 3.30 & 0.94 & Agree \\
\hline 6 & $\begin{array}{l}\text { Principal finishes things despite of obstacles, } \\
\text { difficulties, or discouragements along the way }\end{array}$ & 312 & 3.27 & 0.89 & Agree \\
\hline 7 & $\begin{array}{l}\text { Principal works hard over extended periods and } \\
\text { follows through to achieve goals }\end{array}$ & 312 & 3.39 & 0.82 & Agree \\
\hline & Average & 312 & 3.07 & 0.75 & Agree \\
\hline
\end{tabular}

As shown in Table 2, all items (1-7) had mean rating scores above the criterion level of 2.50. Average mean value was also above the criterion level of 2.50. This implies that the teachers concurred that their principals are courageous in their schools. Therefore, it can be described that that the principals in Osun State secondary schools demonstrated their courageous characters. 
Research Question 2: What are the collaborative characters demonstrated by secondary school principals in Osun State secondary schools?

Table 3: Mean rating of teachers on collaborative characters demonstrated by Secondary School Principals

\begin{tabular}{|l|l|l|l|l|l|}
\hline S/N & ITEMS & N & Mean & SD & Decision \\
\hline 8 & $\begin{array}{l}\text { Principal gets along with staff and builds strong } \\
\text { working relationships }\end{array}$ & 312 & 3.54 & .73 & Agree \\
\hline 9 & $\begin{array}{l}\text { Principal takes a good-natured approach to working } \\
\text { with others }\end{array}$ & 312 & 2.98 & 0.87 & Agree \\
\hline 10 & Principal seeks to resolve differences amicably. & 312 & 3.30 & 0.94 & Agree \\
\hline 11 & $\begin{array}{l}\text { Principal listens patiently and non-defensively when } \\
\text { people question or challenge his/her stance or } \\
\text { opinion. }\end{array}$ & 312 & 2.51 & 1.03 & Agree \\
\hline 12 & $\begin{array}{l}\text { Principal remains open to changing personal opinions } \\
\text { and conduct when circumstances change. }\end{array}$ & 312 & 2.68 & 0.57 & Agree \\
\hline 13 & $\begin{array}{l}\text { Principal senses and values deep connections with } \\
\text { others at all levels within the school and the society }\end{array}$ & 312 & 3.37 & 0.82 & Agree \\
\hline & Average & 312 & 2.95 & 0.83 & Agree \\
\hline
\end{tabular}

According to Table 3, all items (8-13) had mean rating scores above the criterion level of 2.50. Table also depicts that the average mean rating scores was above the criterion level of 2.50 . This is an indication that the teachers attested and affirmed that their principals demonstrated their collaborative characters in Osun State secondary schools. Therefore, it can be described in the study that that the principals in the study area displayed their collaborative characters. 
Research Question 3: What are the accountability characters demonstrated by secondary school principals in Osun State secondary schools?

Table 4: Mean rating of teachers on accountability characters demonstrated by secondary school principals

\begin{tabular}{|l|l|l|l|l|l|}
\hline S/N & ITEMS & N & Mean & SD & Decision \\
\hline 14 & $\begin{array}{l}\text { Principal acknowledges responsibility to justify } \\
\text { decisions, actions, and outcomes }\end{array}$ & 312 & 2.98 & 0.72 & Agree \\
\hline 15 & $\begin{array}{l}\text { Principal takes responsibility and ownership for } \\
\text { his/her decisions }\end{array}$ & 312 & 3.13 & 0.94 & Agree \\
\hline 16 & $\begin{array}{l}\text { Principal encourages and accepts constructive } \\
\text { criticism }\end{array}$ & 312 & 2.96 & 0.73 & Agree \\
\hline 17 & $\begin{array}{l}\text { Principal agrees to be held accountable for } \\
\text { decisions, actions, and outcomes }\end{array}$ & 312 & 3.35 & 0.92 & Agree \\
\hline 18 & $\begin{array}{l}\text { Principal stays attentive and performs duties } \\
\text { thoroughly and well. }\end{array}$ & 312 & 3.00 & 0.96 & Agree \\
\hline 19 & $\begin{array}{l}\text { Principal stands answerable for decisions and } \\
\text { actions }\end{array}$ & 312 & 3.22 & 0.91 & Agree \\
\hline 20 & Principal accepts his/her own mistakes & 312 & 2.99 & 0.62 & Agree \\
\hline & Average & 312 & 3.09 & 0.83 & Agree \\
\hline
\end{tabular}

As shown on Table 4, all items (14-20) had mean rating scores above the criterion level of 2.50. Moreover, average mean rating score was above the criterion level of 2.50. This implies that the teachers observed and acknowledged that their principals demonstrated their accountability characters in the schools. Therefore, it can be described in the study area that principals demonstrated their accountability leadership characters. 
Research Question 4: What are the justice characters demonstrated by secondary school principals in Osun State secondary school?

Table 5: Mean rating of teachers on justice characters demonstrated by secondary school principals

\begin{tabular}{|l|l|l|l|l|l|}
\hline S/N & ITEMS & N & Mean & SD & Decision \\
\hline 21 & $\begin{array}{l}\text { Principal ensures that consequences are appropriate to } \\
\text { the circumstances }\end{array}$ & 312 & 3.37 & 1.02 & Agree \\
\hline 22 & $\begin{array}{l}\text { Principal applies due processes and appropriate } \\
\text { standards for all. }\end{array}$ & 312 & 3.30 & 0.94 & Agree \\
\hline 23 & $\begin{array}{l}\text { Principal ensures that responses and outcomes are } \\
\text { commensurate with the circumstances. }\end{array}$ & 312 & 2.82 & 0.68 & Agree \\
\hline 24 & $\begin{array}{l}\text { Principal ensures that rewards or sanctions fit the } \\
\text { situation. }\end{array}$ & 312 & 2.58 & 0.62 & Agree \\
\hline 25 & $\begin{array}{l}\text { Principal remains impartial and unbiased in the } \\
\text { treatment and judgment of staff }\end{array}$ & 312 & 3.57 & 0.79 & Agree \\
\hline 26 & $\begin{array}{l}\text { Principal is aware of injustices inside and outside the } \\
\text { school and seeks to redress them }\end{array}$ & 312 & 2.53 & 0.61 & Agree \\
\hline & Average & 312 & 3.02 & 0.78 & Agree \\
\hline
\end{tabular}

As shown in Table 5, all items (21-26) had mean rating scores above the criterion level of 2.50. In addition, the average mean value was above the criterion level of 2.50 . This implies that the teachers accepted that their principals demonstrated the justice character listed on the Table. Therefore, it can be described that the principals of secondary schools in the study area demonstrated their leadership justice character.

Research Hypothesis

$\mathrm{H}_{01}$ : There is no significant difference between the courageous characters demonstrated by male and female principals in Osun state secondary schools

Table 6: T-test analysis of teachers' rating of male and female of secondary school principals

\begin{tabular}{ll|llllll}
\hline Source of Variation & $\mathrm{N}$ & Mean & $\begin{array}{l}\text { Standard } \\
\text { Deviation }\end{array}$ & DF & $\begin{array}{l}\text { T- } \\
\text { Cal }\end{array}$ & $\begin{array}{l}\text { T- } \\
\text { Critical }\end{array}$ & Decision \\
\hline Male Principals & 172 & 24.89 & 3.58 & & & & \\
Female Principals & 160 & 20.72 & 3.12 & 310 & 64.91 & 0.612 & $\begin{array}{l}\text { Accepted } \\
\end{array}$ \\
& & & & & & $\mathrm{H}_{0}$ \\
\hline
\end{tabular}

Table 6 shows that mean of male principals (24.89) was higher than their female counterpart (20.72). However, the critical $t$-value was less than calculated $t$-value at the degree of freedom at 0.05 level of significant, this difference was not found to be significant $(t-c a l=64.91 ; d f=310 ; p(0.612)>0.05)$. In view of this, the hypothesis stated that there was no significant difference between the courageous characters demonstrated by male and female principal's male and female principals was accepted. This indicates that there was no significant difference between the courageous characters exhibited by male and female principal's male and female principals. This is indicated that in respective of gender, secondary school 
principals in Osun State were very courageous in their action and decisions to achieve the goals of their schools.

$\mathrm{H}_{02}$ : There is no significant difference between the collaborative characters demonstrated by male and female principals in Osun state secondary schools

Table 7: T-test analysis of teachers' rating of male and female of secondary school principals

\begin{tabular}{lcclcccc}
\hline Source of Variation & N & Mean & $\begin{array}{l}\text { Standard } \\
\text { Deviation }\end{array}$ & DF & $\begin{array}{l}\text { T- } \\
\text { Cal }\end{array}$ & $\begin{array}{l}\text { T- } \\
\text { Critical }\end{array}$ & Decision \\
\hline Male Principals & 172 & 25.85 & 2.27 & & & & \\
Female Principals & 160 & 28.48 & 2.92 & 310 & 71.88 & 0.736 & $\begin{array}{l}\text { Accepted } \\
\mathrm{H}_{0}\end{array}$ \\
\hline
\end{tabular}

Table 7 shows that mean of male principals (25.85) was less than that of their female principals (26.42). Meanwhile, the critical t-value was less than calculated t-value at the degree of freedom at 0.05 level of significant. It implies that the difference was not to be significant $(\mathrm{t}-\mathrm{cal}=71.88 ; \mathrm{df}=310 ; \mathrm{p}(0.736)>0.05)$. In view of this, the hypothesis stated that there was no significant difference between the collaborative characters demonstrated by male and female principals was not rejected. This indicates that there was no significant difference between the collaborative characters demonstrated by male and female principals. It therefore concluded that male and female principals of Osun State secondary schools demonstrated their collaborative characters while discharging their duties.

$\mathrm{H}_{03}$ : There is no significant difference between the accountability characters demonstrated by male and female principals in Osun state secondary schools

Table 8: T-test analysis of teachers' rating of male and female of secondary school principals

\begin{tabular}{|c|c|c|c|c|c|c|c|}
\hline Source of Variation & $\mathrm{N}$ & Mean & $\begin{array}{l}\text { Standard } \\
\text { Deviation }\end{array}$ & $\mathrm{DF}$ & T-Cal & T-Critical & Decision \\
\hline Male Principals & 172 & 29.27 & 2.99 & & & & \\
\hline Female Principals & 160 & 27.24 & 2.78 & 310 & 72.89 & 0.594 & $\begin{array}{l}\text { Accepted } \\
\mathrm{H}_{0}\end{array}$ \\
\hline
\end{tabular}

Table 8 shows that mean of male principals (29.27) was higher than that of their female principals (27.24). However, the critical t-value was less than calculated t-value at the degree of freedom at 0.05 level of significant. This indicates that the difference between male and female was not found to be statistically different ( $\mathrm{t}-\mathrm{cal}=72.89 ; \mathrm{df}=310 ; \mathrm{p}(0.594)>0.05)$. In view of this, the hypothesis that stated that there is no significant difference the accountability characters demonstrated by male and female principals was accepted. This implies that there was no significant difference between the accountability characters demonstrated by male and female principals. The study concluded that male and female principals of Osun State secondary schools demonstrated their accountability characters while discharging their functions in the schools.

$\mathrm{H}_{04}$ : There is no significant difference between the justice characters demonstrated by male and female principals in Osun state secondary schools 
Table 9: T-Test Analysis of Teachers' rating of Male and Female of Secondary School Principals

\begin{tabular}{lccccccc}
\hline Source of Variation & N & Mean & $\begin{array}{l}\text { Standard } \\
\text { Deviation }\end{array}$ & DF & T-Cal & $\begin{array}{c}\text { T- } \\
\text { Critical }\end{array}$ & Decision \\
\hline Male Principals & 172 & 22.39 & 2.77 & & & & \\
Female Principals & 160 & 24.57 & 2.89 & 310 & 69.81 & 0.612 & Accepted \\
& & & & & & & $\mathrm{H}_{0}$ \\
\hline
\end{tabular}

Table 9 depicts that mean of male principals (22.39) was less than that of their female counterpart (26.42). However, the critical t-value was less than calculated t-value at the degree of freedom at 0.05 level of significant. This connotes that the difference between male and female principals was not found to be significant ( $\mathrm{t}-\mathrm{cal}=69.81 ; \mathrm{df}=310 ; \mathrm{p}(0.612)>0.05)$. In respect of this, the hypothesis that stated there was no significant difference between the justice characters demonstrated by male and female principals was not rejected. This implies that there was no significant difference between the justice characters demonstrated by male and female principals. It therefore can be concluded that both male and female principals in Osun State secondary schools demonstrated their justice characters appropriately while discharging their duties.

\subsection{Discussion of Findings}

The results of the findings indicated that the principals in the study area were courageous to withstand difficulty condition and also able to finish things despite of difficulties and discouragements along their way. The results also indicated that principals in the study demonstrated self-assurance in their abilities and actions. They even believed that what they did are right even when they faced adversity. The principals in the study area stayed committed to see things done appropriately and they quickly recovered while facing setbacks. It is therefore worthwhile for the principals to know that their courageous characters may enable them to accomplish the goals of the schools if appropriate demonstrated. The study was in line with the study of Aprigliano (2000) as cited in Rijamampianina (2018) who argued that courage can be continuously developed while interacting between situation and life experiences. The study was equally allied with the study of Barker and Coy (2003) who suggested that courage is required while facing risks that may harm a leader. The study equally concurred with Solomon (1999) who suggested that courage is required when a manager is facing the threat and challenges.

The findings of the study indicated that principals in the study area were taken good-matured approach to work with staff and equally built strong working relationships. As reported in the study, the principals took time to listen and non-defensively when people questioned or challenged their stance or opinion but they were very strategized to resolve differences amicably. It was also noted in the study that the principals conducted themselves appropriately when circumstances changed. At same time, they valued their deep connections with staff at all levels within the schools. It is therefore imperative for the principals of secondary school to know that their collaborative character would maintain team spirit and cooperation in the school and also encourage quick attainment of goals. The study is in line with the statement of Sanaghan and Lohndorf (2015) who disclosed that collaboration occurs when people work with one another within their different schools to achieve in mutual and understanding manner the set of goals and that may not be achieved if working by themselves alone. 
The findings of the study indicated that the principals in the study area acknowledged and responsible for their decisions, actions, and outcomes. This implies that the principals agreed to be held accountable for decisions, actions, and outcomes of things that happen in the schools. They also attentive and performed their duties thoroughly and diligently. Meanwhile, principals allowed constructive criticism, however accepted their own mistakes if arises. The researcher therefore advocates that the principals should always demonstrate accountability characters that would elevate and encourage positive responsibility. The study concurred with different studies of Allen and Dennis (2010); McCall (2012) who disclosed that when leaders are accountable for the feedback they will use it to improve performance. The study equally agreed with the study of Sarmad (2007) who opined that a good leader takes little more of the blame than the credit.

It was found in the study that the principals made it possible that rewards or sanctions fit the situation when applicable. It was also noted in the study that the principals were aware of injustices inside and outside the school and took appropriate action to address them by maintaining impartial and unbiased in the treatment and judgment. This implies that the principals ensure that responses and outcomes are commensurate in any situation when the circumstances arise. The researcher advocates that the principals should uphold justice and remain unbiased in school decision and actions as well as ensuring that rewards or sanctions fit the situation when such happens. The study is in-line with the statement of Bragues (2006) who suggested that justice is required during decision making, conflict, as well as allocation of resources that people value, such as money, property, sex, offices, power, and status.

The result of the findings further indicated that there was no significant difference between the male and female principals in Osun state secondary schools on their leadership characters. This implies that both the male and female principals were very courageous, collaborative, accountable and upheld justice in their various schools. This is an indication that both male and female principals respected their characters and maintained good leadership example. It is therefore imperative for the principals of Osun State secondary schools to demonstrate characters that would be acceptable and help them to be viable in their schools. The study concurred with the findings of Weiss (2000) who reported that leadership behaviors, traits and characteristics were key elements of the institutional success in regardless of gender. Meanwhile, the study contradicted the study of Oakley (2000) who reported that that there were differences between male and female leaders. He further pointed out that those women have less capable leaders than men. However, the study of Oakley (2000) was focused on competency of leaders, whereas, this study focused on leadership character.

\section{Conclusion}

Secondary school's principals cannot underrate their leadership characters as a means of sustaining their reputation. This study has shown that the principals of Osun State secondary schools demonstrated their courageous, collaborative, accountability and justice characters as a means of sustaining their leadership styles and competency. It was also found out in the study that there was no significant difference of leadership characters demonstrated by both male and female principals of Osun State secondary schools. That is why it is imperative and crucial for all principals of Osun State secondary schools to see their leadership characters as strength to their leadership competency and styles. Therefore, the researcher advocates for those secondary school principals in Osun State and other states to see their leadership 
character as means of supporting their style of leadership and competency. The study implicates that principals should protect and sustain their leadership character as a means of strengthening their leadership styles and competency

\section{Recommendations}

Base on the findings the study, the following recommendation were made:

1. Teaching Service Commission (TESCOM) should always do thorough investigation of past records of teachers and also examining the characters needed before appointment to principals' position.

2. State Ministry of Education should always organise termly, quarterly or yearly seminar for the principals on better ways to improve and sustain their leadership characters

3. Principals should see their leadership characters as backbone (strength) to their leadership style and competency, therefore, they should always protect them

4. Principals should use appropriate characters as situation demands.

\section{References}

Allen, J., \& Dennis, M. (2010). Leadership and accountability. Nursing Management (Harrow, London, England: 1994), 17(7), 28-29.

Allen, V. L., \& Klenke, K. (2009). Failed moral decision making in high-profile leaders: A social cognitive study of William Jefgerson Clinton's political leadership. Essay from the Field, 5. Retrieved on July 10, 2019 from http://tesc.innersync.com/documents/ILJ_Fall_2009.pdf\#page $=6$

Barker, C., \& Coy, R. (2003). The 7 heavenly virtues of leadership. Sydney: McGraw-Hill.

Blagescu, M., \& de Las Casas, L. (2005). Pathways to accountability. The GAP Framework. Retrieved from http://www.who.int/entity/management/partnerships/accountability/PathwaysAccountabilityG APFramework.pdflnpapers2://publication/uuid/C35A1094-BC82-44A0-8C1C77324A90CAC1

Bovens, M. (2007). New forms of accountability and EU-Governance. Comparative European Politics.

Bragues, G. (2006). Seek the good life, not money: The Aristotelian approach to business ethics. Journal of Business Ethics, 67(4), 341-357.

Burke, R. J. (2006). Why leaders fail: Exploring the darkside. International Journal of Manpower, 27(1), 91-100. https://doi.org/10.1108/01437720610652862

Covey, S. (2007, December 10th). The Community. Retrieved from The Leader Formula: The 4 things that make a great leader: http://www.stephencovey.com/blog/?p=6

Crossan, M., Gandz, J., \& Seijts, G. (2012). Developing Leadership Character. Ivey Business Journal, JanuaryFebruary. Reprint number qB12TA07

Dillenbourg, P. (1999). What do you mean by ‘collaborative learning?’ In P. Dillenbourg (Ed.), Collaborative - learning: Cognitive and computational approaches (pp.1-19). Oxford: Elsevier

Dulewicz, C., Young M., \& Dulewicz, V. (2005). The relevance of emotional intelligence for leadership performance. Journal of General Management, 30(3), 71-86.

Daft, L. Richard. (2005). The leadership experience. Ohio: South-Western

Gamage, D., Adams D., \& McCormack, (2009). How does a school leader's role influence student achievement? Areview research findings and best practices. Internal Journal of Educational Leadership Preparation, 4(1) (January - March, 2009) 
Gamagee, D., Charles, T, Kimathi, C. K., \& Zachariah K., (2012) The impact of head teachers' supervision of teachers on students' academic performance. Journal of Emerging Trends in Educational Research and Policy Studies (JETERAPS) 3(3): pp299-306 at jeterapsscholarlinkresearch.org

Ibe, B. O. (2007). Winning strategies for transformational leadership. Lagos Nigeria.

Kateb, G. (2004). Courage as a virtue. Social Research,39-72. Retrieved from http://www.jstor.org/stable/40971659

Kohlberg, L. (1976). Moral Stages and Moralization. In T. Lickona (Eds.), Moral development and behaviour: theory, research and social issues. New York: Holt, Rinehart and Winston.

Lello, J. (1993). Accountability in practice. London: Cassell.

MacIntyre, A. (1984). After Virtue. NotreDame. Indiana: University of Notre Dame Press.

McCall, J. J. (2012). Leadership and ethics: Corporate accountability to whom, for what and by what means. Journal of Business Ethics, 38, 133-139.

Mgbodile, T.O. (2004). Instructional leadership in schools. In T.O. Mgbodile (ed). Fundamentals in educational administration and planning, 140-148. Enugu: Magnet Business Enterprise.

Northouse, P. G. (2010). Leadership: Theory and practice (5thed.). Thousand Oaks, CA: Sage.

O’Dwyer, B., Unerman, J. (2007). From functional to social accountability: Transforming the accountability relationship between funders and nongovernmental development organisations. Accounting, Auditing \& Accountability Journal, 20, 446-471.

Ogbiji, J. (2006). Educational administration in classroom. Cross River State, Train the Trainer Workshop, Calaber.

Ogbonnaya, N.O. (2003). School business administration. In Mgbodile, T.O. (Ed). Fundamentals in administration and planning. Enugu: Magnet Business Enterprise.

Palencia, P. V. (2012). Back to essentials: Virtues and character for strategic leaders. Unpublished master thesis, United States Army War College, USA.

Ponnusamy, P. (2010). The Relationship of instructional leadership, Teachers' Organizational Commitment and Students' Achievement in Small Schools. Unpublished Masters Project.

Putnik, G. D., \& Cunha, M. M. (2008). Encyclopedia of Networked and Virtual Organizations United States of America: Information Science Reference (an imprint of IGI Global)

Rijamampianina, R. (2018). Leaders and decision making: a study of the drivers of courage. Problems and Perspectives in Management, 16(1), 320-329.

Sanaghan, P., \& Lohndorf, J. (2015). Collaborative leadership: the new leadership stance. Conference Paper. Retrieved from http://www.academicimpressions.com/news-sign-up

Sarmad, H. (2007). Top 10 leadership qualities that make good leaders. Retrieved on July 18, 2018 from http//:top\%2010\%20Leadership\%20Qualities\%20That\%20Make\%20Good\%20Leaders.htm

Sen, A., Kabak, H.E,. \& Yanginlar, G. (2013). Courageous leadership for the twenty-first century. Procedia - Social and Behavioral Sciences, 75(2), 91 - 101.

Simpson, J. (2009). The Oxford English dictionary online. Oxford, England: Oxford University Press. Retrieved On December 15, 2009 from http://dictionary.oed.com.libaccess.lib. mcmaster.ca.

Sison, A. J. G. (2003). The moral capital of leaders: Why virtue matters. Cheltenham, UK: Edward Elgar.

Solomon, R. (1999). A better way to think about business: How personal integrity leads to corporate success. Oxford: Oxford University Press.

Yukl, G. (2006). Leadership in organisations (6thed.). Upper Saddle River, New Jersey: Pearson Prentice Hall.

Zaccaro, S.J., Kemp, C., \& Bader, P. (2004). Leader traits and attributes. In J. Antonakis, A.T. Cianciolo, \& R.J. Strenberg (Eds.), The nature of leadership (pp. 101-124). Thousand Oaks, CA: Sage Publications. 